\section{Consent to treatment}

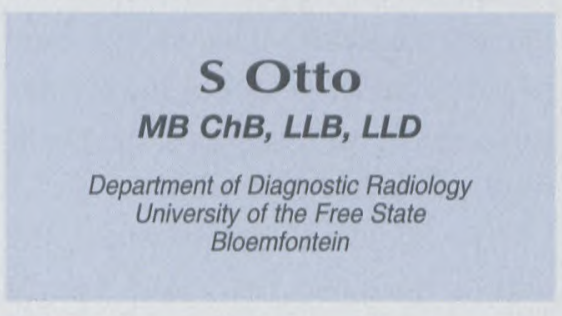

\section{Abstract}

The following article serves as a guideline to the radiologist as to when, how and where consent should be obtained. It is clear that the full participation of the patient in decision-making must be obtained and that the right of the person to self-determination is of utmost importance.

\section{Introduction}

Obtaining a patient's consent is presently accepted as an obligatory prerequisite for the performance of any type of medical treatment, either therapeutic or diagnostic in nature. The doctrine of informed consent has dominated the doctor-patient relationship worldwide for the past 50 years. Although this doctrine has been widely acknowledged, it is frequently ignored.

Human rights movements, especially in Western societies, have placed a particularly high premium on an individual's personal integrity and right of self-determination. The important underlying objective that the doctrine of informed consent was designed to serve is often overlooked or ignored, namely the protection of the patient's fundamental rights of personal autonomy and bodily integrity.

Enabling patients to make treatment choices that are informed by their own and not their doctor's, the medical profession's or even the Government's values and goals is and should be the objective of informed consent. This is of specific importance in South Africa with its ethnically, economically and religiously heterogeneous population and its diverse cultural and belief systems. People's lives are richer and more complex than their physical existence and wellbeing.

Obtaining informed consent is a process of legal discussion including the nature, purpose, risks, effects, advantages and disadvantages of treatment. Consent results in a contract between the doctor and the patient with correction of their unequal status and creation of a therapeutic alliance and symbiosis between law and medicine working for health and quality of life.

South African Law recognised a person's free will to make an informed decision in the case of Stoffberg v. Elliot.'

'In the eyes of the law, every person has certain absolute rights, which the law protects. They are not dependent on statute or upon contract, but they are rights to be respected and one of the rights is absolute security of the person... Any bodily interference with or restraint of a man's person, which is not justified in law, or excused in law or consented to, is a wrong...'

The absolute right to security, dignity and privacy has also been recognised in the Bill of Rights of the South African Constitution. ${ }^{2}$ Informed consent goes beyond a signed document or a list of disclosures. The document is mere evidence of the contract. In general, even where a physician intervenes to the benefit of a patient, s/he will not escape liability if $s /$ he fails to obtain the patient's consent. A vocational right to treat and cure does not justify medical treatment. This was clearly stated in Stoffberg v. Elliot.

\section{Legal aspects surrounding consent}

Any therapeutic or diagnostic procedure fits the legal definition of assault and is an unlawful act. The mere fact that the interference with a person's body is in the nature of recognised medical treatment does not provide grounds for justification.

Consent can take two forms:

1. Consent to injury, e.g. when an operation is performed, the patient consented to the wound being inflicted.

2. Consent to the risk of injury, e.g. consenting to the procedure well knowing that it might have complications or side-effects - the patient voluntarily assumes the risk. 'Volenti no fit iniuria! $^{\text {33 }}$

\section{Requirements for consent}

\section{The person giving consent}

In principle consent must be given by the prejudiced person him/herself. It can only be given by another person in exceptional circumstances. 


\section{Consent must be given voluntarily}

Consent must be given freely and without any constraint. Consent is invalid if obtained through using physical force or if a patient has been persuaded by fraudulent misrepresentation.

If consent was obtained by an offer of financial gain, it will be considered not voluntary. This raises the question of consent for participation in research projects where meal tickets or financial rewards are offered.

\section{The form of consent}

In South African Law, no distinction is made between the validity of written or implied consent. Written consent usually supplies adequate proof. Implied consent can be accepted in cases of non-invasive procedures when a person capable of forming an intent submits him/herself to treatment without resistance or protest.

\section{Capacity}

The person who consents must be able to understand and retain information relevant to the decision, to believe and validate the information and to weigh the information in balance to arrive at a decision.

The following aspects influence a person's capability:

Age: In South African Law it is accepted that a child above the age of $14 \mathrm{can}$ form an intent. Thus any person above the age of 14 years can consent to non-invasive treatment. This is the age prescribed in the Termination of Pregnancy Act. ${ }^{4}$ This implies that the confidentiality arising from the doctorpatient relationship must be respected from the age of 14 years.

Consent to operations and similar invasive procedures can only be given from the age of 18 years. This is prescribed by the Child Care Act. ${ }^{5}$ Section 39(2) authorises the Medical Superintendent of an institution to consent in the case of a life-threatening or impairing condition that can lead to loss of life or serious and permanent physical injury or disability. Please note that this section does not allow consent when unreasonably withheld by parents. In these cases the Supreme Court, as upper guardian for all children, must be approached.

Mental capacity: Mentally ill persons are not always incapable of making decisions regarding their self-determination. The mere fact that a person is institutionalised should not exclude that person from making decisions regarding his/her own person. Where a patient is not able to form intent, the Mental Health Act ${ }^{6}$ prescribes a procedure in this regard.

Married women: South African Law does not restrict married women from making their own decisions.

\section{Informed consent}

Informed consent is more than getting a paper signed or a list of disclosures. The doctor has an obligation to educate the patient regarding the diagnosis and the therapeutic options available, including the option of doing nothing. It is a process in the form of a discussion including the nature of treatment, the purpose of the treatment, the risks involved and the effects, advantages and disadvantages of the procedures. It is insensitive to obtain consent the night before the procedure is performed when the patient is under emotional strain or even sedation. This is the time when the patient needs emotional support and encouragement and not the time to hear a fearsome list of possible complications.
During the discussion process the patient must be given the opportunity to reflect, to ask questions and to change his/her mind. The issue of language becomes most important. The patient has the right to have the information translated. The ability of the patient to understand the controversies surrounding the proposed treatment must be taken into account.

The standard against which the duty is measured has always been a professional judgement measured by what reasonable practitioners would have disclosed after all surrounding factors had been considered. This was confirmed by Judge Watermeyer in the case of Richter and Another v. Estate Hamman. $^{8}$

The emphasis has, however, shifted recently to accommodate the patient's participation. It requires that sufficient information should be furnished to a patient to enable him to make an intelligent decision relating to the treatment. This has been accepted in South African Law in recent unreported cases in the Western Cape Supreme Court as well as in the United Kingdom and Canada. ${ }^{9}$

A patient wants to hear five main things:

- What is wrong with me?

- What caused it?

- What should I do about it?

- How much will it cost in time, money, pain and disability?

- How long will it take?

\section{The doctor obtaining the consent}

The referring doctor must obtain the consent of the patient for the referral as well as for the procedure - this includes available alternatives. ${ }^{10}$

The radiologist accepting the patient takes full responsibility for the 
Shaping the future

\section{together}

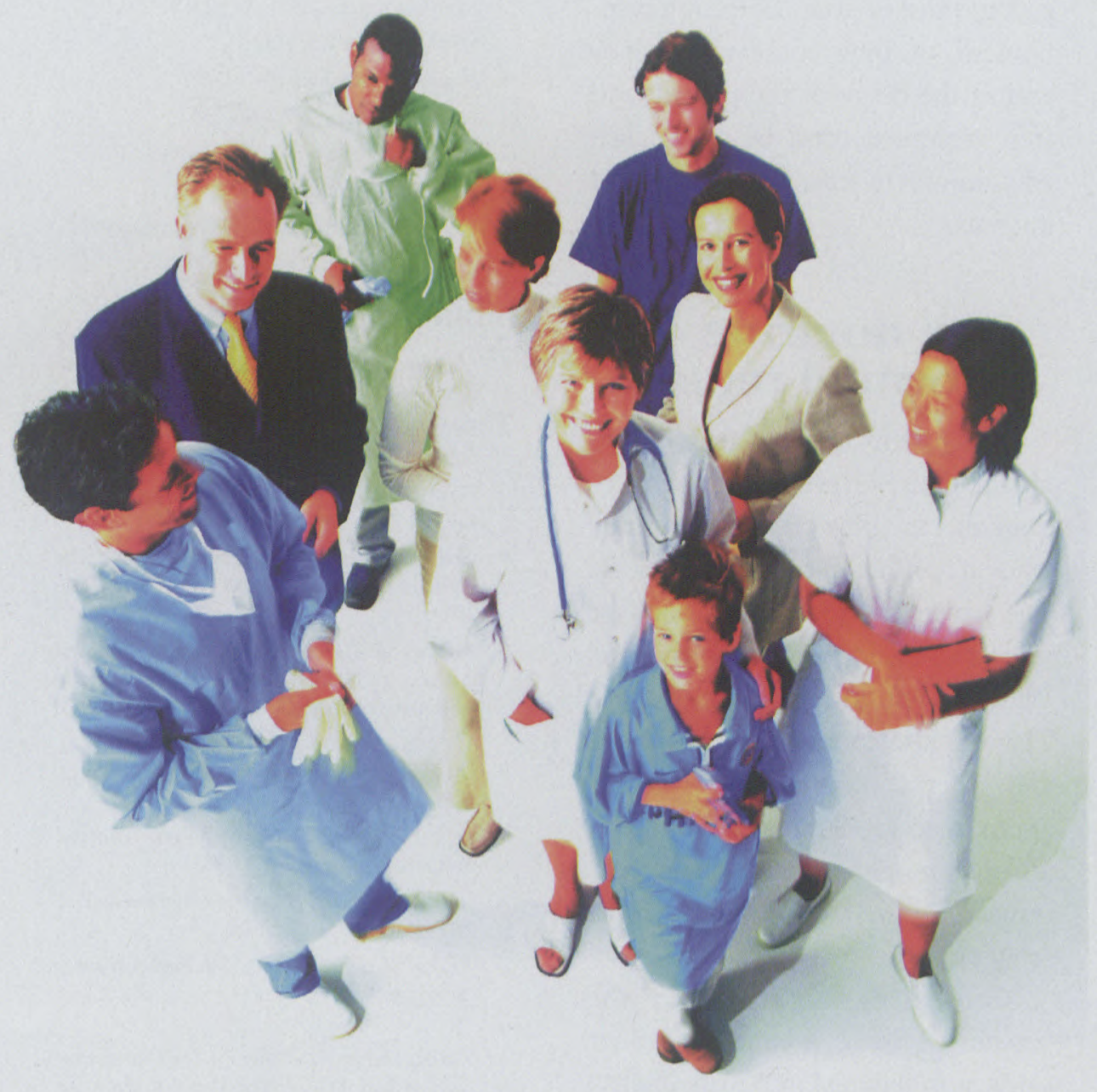

Philips Medical Systems

Agilent Technology HGS

Adac Laboratories

ATL Ultrasound

Marconi

Tel: (0II) 47I-5050

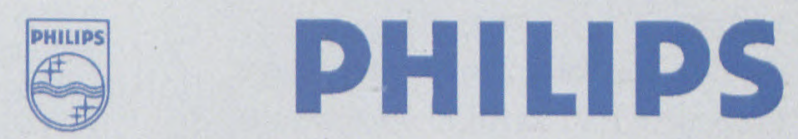

website: www.philipsmedical.co.za Let's make things better. 
treatment of the patient during the specific procedure.

In Lymbery v. Jefferies, ${ }^{11}$ the patient was referred for deep X-ray treatment to a radiographer at Pretoria Hospital. The patient sustained serious burns that needed to be treated with skin transplants. It was claimed that the respondent had been negligent in referring the appellant for treatment well knowing that the person was not a qualified radiologist, but a radiographer. The appeal court upheld that: 'If a Medical Practitioner or Surgeon advises his patient to be treated by some third person, either because it is a treatment he cannot carry out himself or which he is customary to entrust to a third person, then the latter does not as a general rule, act as the agent of the Medical Practitioner or Surgeon."11

The 'captain of the ship doctrine' was not accepted in South African Law, and it is according to Strydom and Strauss ${ }^{12}$ insupportable and should not go further than the vicarious liability of the employer in the employer-employee relationship.

\section{Treatment of a patient without consent}

A patient can be treated without consent in the following circumstances:

1. Protection of the public interest, e.g. when a person is suffering from a contagious disease. Treatment might even be given against the patient's wishes.

2. In case of an emergency where the patient is in a critical unconscious condition. The principle used is the doctrine of 'negotiorum gestio' or spontaneous agency whereby the intervener acts on behalf of the other person. Strydom and Strauss ${ }^{13}$ set out the requirements as follows: $(i)$ there must be a real emergency; (ii) the patient must be aware of the intervention; (iii) the intervention must not be against the desire of the patient; and (iv) treatment must be undertaken with the aim to serve the patient's best interests.

\section{The doctrine of informed refusal}

The patient also has the right to obtain, refuse or postpone the procedure and the physician must tolerate what to him/her may seem capricious. The patient's wishes must always be respected, e.g. in the case of Jehovah's Witnesses refusing blood transfusions. This was also confirmed in Phillips v. De Klerk, where the doctor approached the Supreme Court with an ex parte application to obtain permission to give blood and the Court set it aside. ${ }^{14}$

Consent is lacking when the patient is sedated, a language barrier exists, it is obtained in a rush, if alternatives are not discussed, if the procedure extends beyond the scope for which consent was obtained, if it is not understood and/or if any intimidation or misrepresentation occur.

\section{References}

1. Stoffberg v Elliot 1923 CPD 148.

2. South African Constitution: Act 200 of 1993.

3. Romeinse Reg en Romeins-Hollandse Reg: De Groot 335, 8; VOET 47, 10, 4.
4. Choice of Termination of Pregnancy Act 92 of 1996.

5. Child Care Act Amendment 96 of 1996

6. Mental Health Act 18 of 1973.

7. McQuoid-Mason and Strauss 17 LAWSA 1983: 147.

8. Richter and Another $\mathrm{v}$ Estate Hamman; 1976(3) S A 226 (C) 232; 9-11.

9. Reibl v Hughes (1977) 78 DLR 3d 35, 52. Male v Hopmans (1965) 54 DLR 2d 592, 595 (1967) DLR 2d 105, 113.

10. Strauss and Strydom 1967: 221.

11. Limbery v Jefferies 1925 AD 236.

12. Strydom \& Strauss 1967: 283 footnote 112.

13. Strydom \& Strauss 1967: 238.

14. Phillips v De Klerk (1983) TPD (unreported).

\section{Bibliography}

1. Claassen NJB, Verschoor T. Medical Negligence in South Africa. Pretoria: Digma, 1992.

2. Deutsch E. The right not to be treated or to refuse treatment. Med Law 1989; 7: 433-438.

3. Golan J, Ben Hur N. Informed consent in plastic surgery. Med Law 1983; 2: 113-115.

4. Green Koopersmith ER. Informed consent. The problem of causation. Med Law 1984; 3: 231236.

5. McLean SAM, McKay AJ. Consent in medical practice. In: McLean SAM, ed. Legal Issues in Medicine: Aldershot: Gower Publishing, 1981: 96-113.

6. Ott $\mathrm{H}$. The right to know: Informed consent. Med Law 1989; 7: 439-441.

7. Snyman CR. Strafreg. 4th ed. Durban: Butterworths, 1986.

8. Strauss SA. Doctor, Patient and the Law. 2nd ed. Pretoria: IL van Schaik, 1984.

9. Strauss SA, Strydom MJ. Die Suid-Afrikaanse Geneeskundige Reg. Pretoria: IL van Schaik, 1967.

10. Van der Merwe NJ, Olivier PJJ. Die Onregmatige Daad in Suid-Afrika. 5th ed. Pretoria: JP van der Walt, 1985.

11. Van Oosten FFN. Informed consent: Patient rights and the doctor's duty of disclosure in South Africa. Med Law 1989; 7: 443-456.

12. Lymbery v Jefferies 1925 AD 236.

13. Richter and Another v Estate Hamman; 1976 (3) S A 226 (C).

14. Stoffberg v Elliot; 1923 CPD 148.

15. Chatterton v Gerson (1981) 1 QB 432.

16. Reibl v Hughes (1977) 78 DUR 3d 35; (1981) 114 DLR 3d 1.

17. Male v Hopmans (1965) 54 DLR 2d 592 (1967) 64 DCL 2d 105. 